\title{
Catch-as-Catch-Can: A Case Note on Grokster
}

\section{Citation}

Urs Gasser \& John G. Palfrey, Jr., Catch-as-Catch-Can: A Case Note on Grokster, 78 Swiss Review of Business Law and Financial Market Law 119.

\section{Permanent link}

http://nrs.harvard.edu/urn-3:HUL.InstRepos:2794936

\section{Terms of Use}

This article was downloaded from Harvard University's DASH repository, and is made available under the terms and conditions applicable to Other Posted Material, as set forth at http:// nrs.harvard.edu/urn-3:HUL.InstRepos:dash.current.terms-of-use\#LAA

\section{Share Your Story}

The Harvard community has made this article openly available.

Please share how this access benefits you. Submit a story.

Accessibility 


\title{
Catch-as-Catch-Can: A Case Note On Grokster
}

\author{
By Prof. Urs Gasser* and Prof. John G. Palfrey, Jr.**
}

In summer 2005, the United States Supreme Court issued a decision which is surely destined to play a significant role in the interrelation between law and technology in the coming years. The case, MetroGoldwyn-Mayer Studios Inc., et al. v. Grokster, Ltd., et al., pitted copyright holders against the operators of certain peer-to-peer online file-sharing services and was awaited by many in both the legal and technology communities as a referendum on the landmark legal precedent set in the «Sony-Betamax» case. The Sony case came to represent the legal standard for determining when manufacturers of "dual-use technology» - technology capable of both legally noninfringing and infringing uses - should be given a safe harbor from liability for acts on the part of their consumers which violated copyright law. Surprisingly, the Supreme Court's decision did not center around an af-

\section{Summary}

I. The Problem

II. The Ruling

III. Comments

1. The Sony Controversy

2. (Re-)Introducing the Inducement Rule

3. Grokster's Potential Impact

4. Conclusion

\section{The Problem}

Grokster Ltd, and StreamCast Networks, Inc. have distributed free software products that allow In-

* Associate Professor \& Director, Research Center for Information Law, University of St. Gallen; Faculty Fellow, Berkman Center for Internet \& Society, Harvard Law School.

** Clinical Professor of Law \& Executive Director, Berkman Center for Internet \& Society, Harvard Law School. Thanks to our colleague James Thurman for research assistance and support. An extended version of this article is available at http://papers.ssrn.com/sol3/papers.cfm?abstract_id $=869030$.

I Grokster relied on FastTrack technology which had been developed and licensed to Grokster by a third party. StreamCast's software was called «Morpheus» and relied on Gnutella technology. In the course of litigation, Stream- firmation or rejection of the Sony ruling; rather the Court based their opinion on a common law principle which, they held, was not preempted by the holding in Sony. The «inducement» to infringe copyright, although not a completely novel cause of action, has been perceived by some commentators to introduce a change in the legal landscape of secondary liability for copyright infringement. In this article, we provide a brief exposition of the Court's decision and discuss the disposition of the decision including the implication of the two concurring opinions. We also speculate on the impact that the Court's decision will have on the technology sector and on technological innovation in particular. Ultimately, we grapple with new questions which the decision has presented for industry and the continued existence of peer-to-peer file-sharing.

ternet users to share electronic files through so-called peer-to-peer $(P 2 P)$ networks. P2P networking, in essence, is a system of information exchange where the transfer of data is effected directly from one user's computer to another. P2P networks differ from centralized systems where users communicate through a central server that mediates the exchange of information or files among them. Software such as Grokster and Morpheus can be used by individuals to share any type of digital file, including, for instance, public domain works. However, it is common wisdom that users have prominently used $\mathrm{P} 2 \mathrm{P}$ networks to share copyrighted materials such as music and video files without authorization. Against this backdrop, motion picture studios, recording companies, songwriters, and music publishers (a group hereinafter referred to as «MGM») sued Grokster and StreamCast for their users' copyright infringements, alleging that they knowingly and intentionally distributed their software products to enable users to reproduce and distribute copyrighted works in violation of U.S. Copyright. The District Court for the Central District of California granted partial summary judgment for Grokster and StreamCast on issues of contributory

Cast later switched over to Neonet technology as a basis for its software. This development, however, was apparently not deemed to be relevant to the Court's decision. 
and vicarious infringement. ${ }^{2} \mathrm{MGM}$ appealed and the United States Court of Appeals for the Ninth Circuit affirmed the District Court's ruling. ${ }^{3}$ The U.S. Supreme Court granted certiorari. ${ }^{4}$ The key question before the Supreme Court was: under what circumstances can the distributor of a product (here: software) capable of both lawful and unlawful use (here: sharing unprotected files as well as copyrighted materials) be held liable for acts of copyright infringement perpetrated by third parties using the product. The appeal of the case represented both a challenge of the lower court rulings in the Grokster matter but also the principle settled in the 1984 Supreme Court case, Sony Corp. of America v. Universal City Studios, Inc. as to secondary liability in copyright. Observers in the technology and media fields agreed that much hung in the balance.

\section{The Ruling}

In the landmark case Metro-Goldwyn-Mayer Studios Inc., et al. v. Grokster, Ltd., et al., ${ }^{5}$ the Supreme Court held that there was sufficient evidence to find Grokster and StreamCast liable of infringement under a theory of inducement of infringement. In order to understand the ruling, one must first recall an important feature of U.S. copyright law and a precedent that played an important role in the Grokster litigation.

Under U.S. law, not only the direct or primary infringer, but also parties with less direct involvement in the infringement might be held liable for copyright infringement. Third-party (also known as secondary) liability in copyright traditionally follows one of two theories: contributory liability or vicarious liability. Contributory liability requires that the secondary infringer knew or had reason to know of the direct infringement and that the secondary infringer materially contributed to that infringement. ${ }^{6}$ Vicarious liability, by contrast, does not require knowledge.

2 Metro-Goldwyn-Mayer Studios Inc., et al. v. Grokster, Ltd, et al., 259 F. Supp.2d 1029 (C.D. Cal., 2003).

3 Metro-Goldwyn-Mayer Studios Inc., et al. v. Grokster, Ltd., et al., 380 F.3d 1154 (9 $9^{\text {th }}$ Cir., 2004).

4 Metro-Goldwyn-Mayer Studios Inc., et al. v. Grokster, Ltd., et al., 125 S. Ct. 686, 160 L.Ed.2d 518 (2004).

125 S.Ct. 2764 (2005).

6 Gershwin Pub. Corp. v. Columbia Artists Management, Inc., 443 F.2d 1159 (2d Cir. 1971).
Rather, it requires that the third party has some measure of control over the primary party. Further, the third party must enjoy a direct financial benefit from the infringement to be held liable under the vicarious liability doctrine. ${ }^{7}$

The U.S. Supreme Court has dealt with secondary copyright infringement in only one recent case - a precedent that the parties in Grokster as well as many amici regarded as key in resolving the Grokster controversy. In Sony Corp. of America v. Universal City Studios, Inc., ${ }^{8}$ Universal Studios and Disney sued Sony for contributory infringement caused by consumers copying TV programs using Sony's videocassette recorders (VCRs). However, at the trial on the merits, evidence showed that the principal use of the VCR was for non-infringing uses such as time-shifting. ${ }^{9}$ Further, there was no evidence that Sony had intent to promote infringing uses. ${ }^{10}$ Consequently, the only basis for imposing liability was on the theory of contributory infringement arising from the very distribution of VCRs to consumers with the knowledge that some would use them to infringe a commercial product." Reflecting a traditional doctrine from patent law, the Supreme Court held Sony could not be faulted solely on the basis of the distribution of VCRs, because the device was «capable of commercially significant noninfringing uses.. ${ }^{12}$

The Ninth Circuit applied the Sony doctrine in favor of Grokster and StreamCast by giving it a broad interpretation, holding that whenever a product is capable of substantial non-infringing uses, the producer or distributor cannot (or only under very specific circumstances) be held contributorily liable for a third party's infringing use of it. Based on this view of Sony on the one hand and the Circuit Court's finding that the defendant's software was capable of substantial lawful uses - like sharing public domain works on the other hand, the Ninth Circuit ruled that neither

7 Fonovisa, Inc. v. Cherry Auction, Inc., 76 F.3d 259 ( $9^{\text {th }}$ Cir. 1996). For liability in the file-sharing context, see A\&M Records, Inc. v. Napster, Inc., 239 F.3d 1004 ( $9^{\text {th }}$ Cir. 2001).

$8 \quad 464$ U.S. 417 (1984).

9 Time-shifting refers to the practice of recording television programs so that they may be viewed at a later time.

10 The recording of programs for the purpose of selling them to third parties or for building a movie library, for instance.

11 Id. at 439 .

$12 \quad I d$. at 442. 
company could be held liable, since there was no evidence that their software afforded them knowledge of specific unlawful uses.

In the majority opinion, the U.S. Supreme Court disagreed with the Ninth Circuit's broad reading of Sony, but left further consideration of the rule «for a day when that may be required, holding that the Sony doctrine did not exclusively require the distributor to have actual knowledge of specific unlawful acts on the part of third party users of the distributor's product in order for secondary liability for infringement to attach. According to this opinion, Sony did not eliminate or replace common law theories of liability. The primary liability issue before the Court was ultimately answered by adopting an alternative theory of liability rooted in patent law, the so-called inducement rule. The Court held:

We adopt [the inducement rule] here, holding that one who distributes a device with the object of promoting its use to infringe copyright, as shown by clear expression or other affirmative steps taken to foster infringement, is liable for the resulting acts of infringement by third parties. ${ }^{13}$

The Supreme Court held that there was sufficient evidence to find Grokster and StreamCast liable of infringement under this theory of enticement or inducement of infringement. Three features of the evidence of intent were particularly important in this context: First, StreamCast and Grokster were targeting users of the former file-sharing service Napster as internal documents and advertisements revealed. Second, neither company attempted to develop filtering tools or other mechanisms to reduce the infringing activity using their software. In an important footnote, the Supreme Court made clear that this failure to take affirmative steps to prevent infringement would not be sufficient to find contributory infringement liability in cases of dual-purpose devices. However, the Court argued that this piece of evidence underscored the defendants' intentional facilitation of their users' infringements. Third, the fact that StreamCast and Grokster made money by selling advertising space for ads directed to the screens of computers running their software complemented the direct evidence of unlawful objective, since sthe extent of the software's use determines the gain to the distributors, the commercial sense of their enterprise turns on high-volume use, which the record shows is infringing.. ${ }^{14}$ Again, this evidence alone would not justify an inference of unlawful intent, but acquired added significance «in the entire record's context.» ${ }^{15}$

Based on the theory of inducement and according to this evidence, the Supreme Court remanded the case to the lower courts for a determination of StreamCast's and Grokster's liability.

\section{Comments}

The Grokster case raises a multitude of equally interesting and complex questions at the intersection of law, technology, and digital entrepreneurship. They range from specific doctrinal problems to policy issues, but also include a set of fact-specific questions. In this section, we focus on three aspects that are particularly interesting and controversial. First, we seek to analyze to what extent Grokster affects the abovementioned Sony standard. Second, we take a closer look at the alternative theory of secondary liability that the Supreme Court introduced in Grokster («inducement rule»). Finally, we offer some thoughts about the possible impact of Grokster on the digital media landscape.

\section{The Sony Controversy}

As mentioned above, the interpretation of the Sony doctrine has been at the core of the litigation all the way up to the Supreme Court. Both the parties as well as many amici asked the Supreme Court to clarify the Sony doctrine and its application in the digital age - and many suggested to the Court that they ought to re-affirm its core holding. ${ }^{16}$ The Supreme Court, however, has not provided a comprehensive answer, but clearly rejected the Ninth Circuit Court's application of Sony.

After all the back-and-forth, where does Grokster leave us as far as the Sony standard is concerned? In our view, the baseline is that Grokster has not changed

$14 \quad I d$ at 2782

is $I d$.

16 See, e.g., Brief for Petitioners, at 17, Metro-GoldwynMayer Studios Inc., et al. v. Grokster, Ltd., et al., $125 \mathrm{~S}$.Ct. 2764 (2005) (No. 04-480); Brief for Respondents, at 1314, (No. 04-480); Brief of the Business Software Alliance as Amicus Curiae (No. 04-480); Brief of Amici Curiae Law Professors, Economics Professors, and Treatise Authors (No. 04-480). 
the Sony standard, which was a sound decision on the part of the Court. While the majority opinion avoided revisiting Sony, concurring opinions drafted by Justice Ginsburg and Justice Breyer dealt more extensively with the Sony rule. These Justices read Sony as a matter of substantive law - in the same way. «Liability under our jurisprudence,» so Justice Ginsburg, «may be predicated on actively encouraging (or inducing) infringement through specific acts ... or on distributing a product distributees use to infringe copyrights, if the product is not capable of isubstantial) or (commercially significant) noninfringing uses.» ${ }^{17}$ Similarly, Justice Breyer defines Sony as a test «whether the company's product is capable of substantial or commercially significant noninfringing uses. $)^{18}$ However, the two concurring opinions are evidence that there is significant disagreement regarding the question as to when evidence satisfies Sony's test. More precisely, the two concurring opinions suggest a different level of concrete evidence that is required to fall under the Sony safe harbor. It remains to be seen how this disagreement will play out and what the practical impacts on the safe harbor provided by the Sony doctrine will be. ${ }^{19}$ In the event that the Supreme Court adopts Justice Ginsburg's approach, putting a heavier evidentiary burden on defendants, there are good reasons to believe that Sony would provide less protection for entrepreneurs engaged in the design and distribution of technologies. Indeed, we agree with the analysis ${ }^{20}$ that a requirement to provide detailed evidence in order to earn Sony's shelter is likely to increase the copyright holder's incentive to litigate, while negatively affecting an entrepreneur's cost-benefit analysis when deciding whether she shall engage in the development, production, or distribution of a new technology vis-à-vis the specter of extensive and expensive trials. This, in turn, would unnecessarily shift the delicate balance «between a copyright holder's legitimate demand for effective - not merely symbolic - protection of the statutory monopoly, and the rights of others freely to

17 Id., at 2783 (Citations omitted) (emphasis added)

$18 \quad I d$., at 2789 (Citations omitted).

19 See, e.g., Richard Raysman and Peter Brown, «MGM v. Grokster): Finding Another Theory of Secondary Liability, N.Y. L.J., July 12, 2005

20 MGM et al., 125 S. Ct., at 2792 et seq. (Breyer, J., concurring). engage in substantially unrelated areas of commerce..$\rangle^{21}$

\section{2. (Re-)Introducing the Inducement Rule}

As discussed above, the Supreme Court disagreed in its Grokster ruling with the Ninth Circuit regarding the proper understanding of the limiting effect of the Sony rule. In essence, the disagreement boils down to the question under what circumstances a defendant can be liable for contributory infringement even when its actions are taken in connection with a product that is capable of substantial noninfringing uses. In contrast to the Ninth Circuit's broader interpretation of the scope of the Sony safe harbor, the Supreme Court held that the Sony holding would not preclude liability where there was evidence of «statements or actions directed to promoting infringement. $\rangle^{22}$ Thus, the Supreme Court recognized that active inducement is available as an alternative theory of contributory infringement after Sony. As noted above, the Grokster court adopted the inducement rule from patent law, from which the Sony court also adopted the «capable of substantial noninfringing uses» standard. ${ }^{23}$ As a result, the Supreme Court synchronized secondary liability under copyright law with patent law to the extent that a demonstration of substantial noninfringing uses is a defense to contributory infringement, but not a defense to liability under the (active) inducement theory. ${ }^{24}$ Consequently, someone does not earn Sony's safe harbor «who distributes a device with the object of promoting its use to infringe copyright, as shown by clear expression or other affirmative steps

21 Sony, 464 U.S. at 442. See also Richard M. Myrick, Note: Peer-to-Peer and Substantial Noninfringing Use: Giving the Term «Substantial» Some Meaning, 12 J. Intell. Prop. $L$., Spring 2005, at 539, 559-65.

22 MGM et al., I25 S. Ct, at 2779

23 See 35 U.S.C. \& 271 (c).

24 As the American Intellectual Property Law Association pointed out in its brief, inducement liability was subsumed under contributory liability in case law prior to the 1952 Patent Act. The 1952 Act codified inducement liability separately from that of contributory liability. Amicus $\mathrm{Cu}$ riae Brief of the American Intellectual Property Law Association, at 16, Metro-Goldwyn-Mayer Studios Inc., et al. v. Grokster, Ltd., et al. (Case No. 04-480). See also in particular the reference to the Henry case where the defendant was held liable of inducement despite the fact that the product at issue was capable of substantial noninfringing uses. $\mathrm{Id}$. at 17. 
taken to foster infringement. ${ }^{25}$ Such a person is liable for the resulting acts of infringement by third parties even if their technology is capable of substantial noninfringing uses.

Although the «inducement rule» was formally adopted in Grokster, one can find earlier references to the concept of «inducement» of infringement in the copyright context and with regard to contributory liability. Perhaps the most prominent formulation goes back to the Second Circuit's decision Gershwin Publishing Corp. v. Columbia Artists Management, Inc. ${ }^{26}$ The Gershwin court held that «one who, with knowledge of the infringing activity, induces, causes or materially contributes to the infringing conduct of another, may be held liable as a (contributory) infringer. $»^{27}$ Thereafter, the attribution of liability for «inducing,» 《causing» or «materially contributing» to infringement seems to have become widespread throughout the nation's federal courts. ${ }^{28}$ The Sony court, too-albeit focusing on limitations to contributory liability - made references to liability based on inducement of infringement when distinguishing its own facts from other cases. ${ }^{29}$

In Grokster, the Supreme Court mentioned as prime examples of uactive steps ... taken to encourage direct infringement» the advertisement of an infringing use or the instruction how to engage in infringing use, which in turn "show an affirmative intent that the product be used to infringe.) On the other end of the spectrum, the Court emphasized that neither the mere knowledge of infringing potential or of actual infringing uses, nor "ordinary acts incident to product distribution, such as offering customers technical support or product updates, would support liability in themselves, since[t]he inducement rule ... premises liability on purposeful, culpable expression and conduct.... $\rangle^{30}$

25 MGM et al., $125 \mathrm{~S}$. Ct., at 2780; see also id., at 2779-80.

$26 \quad 443$ F.2d 1159 (2d Cir. 1971).

${ }_{27} I d$, at 1162 (emphasis added).

28 See, e.g., CoStar Group, Inc. v. LoopNet, Inc., 373 F.3d 544 (4h Cir. 2004); Alcatel USA, Inc. v. DGI Technologies, Inc., 166 F.3d 772 (5 $5^{\text {th }}$ Cir. 1999), reh'g and reh'g en banc denied, 180 F.3d 267 ( $5^{\text {th }}$ Cir. 1999); Bridgeport Music, Inc. v. Diamond Time, Ltd., 37I F.3d 883 (6th Cir. 2004); Playboy Enterprises, Inc. v. Russ Hardenburgh, Inc., 982 F. Supp. 503 (N.D. Ohio 1997); Ellison v. Robertson, 357 F.3d 1072 (9 $9^{\text {th }}$ Cir. 2004).

29 Sony, 464 U.S. at 438-39 («Sony certainly does not intentionally [induce]' its customers to make infringing uses of respondents' copyrights .... .») (citation omitted).

$30 \quad M G M$ et al., $125 \mathrm{~S}$. Ct., at 2780.
Despite those lines of demarcation, it remains unclear what, exactly, constitutes (inducement» under the Grokster standard. ${ }^{31}$ The application of the standard to the facts presented in the case itself indicates that there is an area of uncertainty surrounding the inducement rule. ${ }^{32}$ Beyond the facts of the case, for instance, it remains an open question under what conditions a business model would be considered to effectively induce others to infringe copyright. Similarly, it is unclear what kinds of advertisement would show an affirmative intent that the product be used for infringing uses, or what reasonable steps must be taken to stop people from using the product for infringing uses in order to avoid that the lack of such steps may be regarded as evidence underscoring intentional facilitation of users' infringements. ${ }^{33}$ Businesses are also left without any clear guidance as to what response to take once they become aware that their products are being put to infringing uses. ${ }^{34}$ This sort of uncertainty may have a negative impact on both innovation and digital entrepreneurship.

Before we move to the discussion of Grokster's impact on the digital ecosystem, however, it is noteworthy that similarly broad and vague inducement standards have been proposed by policymakers and legislators on both sides of the Atlantic. ${ }^{35}$ In the U.S.,

${ }^{31}$ See, e.g., Andrew Deutsch, File-Swapping Services May Be Liable for Inducing Copyright Infringement, Supreme Court Rules, Mondaq (June 29, 2005) 2005 WLNR 10370986. But, see generally, Amicus Curiae Brief of the American Intellectual Property Law Association, MetroGoldwyn-Mayer Studios Inc., et al. v. Grokster, Ltd., et al. (Case No. 04-480) where the AIPLA lists the elements of inducement in patent law and cites case law applying the inducement rule. One can infer that application of the rule in the copyright context would not be any more difficult or unclear than it has been in the patent context. Yet, Mark Lemley contends that the case law defining inducement liablity within the patent context is far from clear and consistent. See generally, Mark Lemley, Inducing Patent Infringement (Stanford Public Law and Legal Theory Working Paper Series No. 110, July, 2005), http://ssrn. com/abstract $=772264$.

32 As discussed above, the Supreme Court regarded three features of the evidence of intent as particularly important, but at the same time made clear that either of two of them standing alone would not be sufficient to find contributory infringement liability.

33 John Palfrey, The Entrepreneur in a Post-Grokster World, available at http://blogs.law.harvard.edu/palfrey/2005/ 06/27.

34 Coming to Grips with Grokster, Bus. Wk., July 11, 2005, 2005 WLNR 10640722.

35 For an overview of proposed legislation in the digital media context, see Urs Gasser et al., Copyright and Digital 
for instance, the Intentional Inducement of Copyright Infringements Act of 2004 (INDUCE Act) ${ }^{36}$ sponsored by a bipartisan coalition of senators, would enable civil lawsuits by copyright holders against any party that «induces» illegal copying by another. The proposed Act responded to the District Court's decision in Grokster and temporarily received additional support following the Ninth Circuit's affirmation of the decision, but it is doubtful whether the bill will make further headway in the aftermath of the Supreme Court's decision. ${ }^{37}$

The Commission of the European Communities, finally, recently presented a proposal for an EU-Directive as well as a proposal for a Council Framework Decision aimed at combatting IP offences. ${ }^{38}$ The proposals seek to criminalize IP infringement of a commercial nature and harmonize legal penalties for such infringement among the Member States. ${ }^{39}$ In particular, Article 3 of the proposed Directive would require that «all intentional infringements of an intellectual property right on a commercial scale, and attempting, aiding or abetting and inciting such infringements, are treated as criminal offences. $)^{40}$

For the reasons mentioned above and further discussed in the next section, the broadness and vague-

Media in a Post-Napster World, Version 2, Updated January 2005 , available at http://cyber.law.harvard.edu/media/ files/wp2005.pdf and Urs Gasser, International Supplement to Copyright and Digital Media in a Post-Napster World, available via http://cyber.law.harvard.edu/media/ wpsupplement2005.

36 S. 2560, 108th Cong. (2004).

37 For criticism of the Act, see generally, Jason Schultz, Secondary Liability Under the Copyright Act: Article: The False Origins of the Induce Act, 32 N. Ky. L. Rev. 527 (2005) (suggesting that the Act was derived from the dissent in Sony and thus represents a departure from Sony's clear safe harbor rule). See also, Jay Dratler, Jr., CommonSense (Federal) Common Law Adrift in a Statutory Sea, or Why Grokster was a Unanimous Decision, (Univ. of Akron School of Law, Public Law \& Legal Theory Working Paper Series No. 05-13, Aug., 2005), http://ssrn.com/abstract $=792344$ (arguing that the Common Law operates much more effectively in the regulation of technology than do statutory approaches).

38 See Bruce Gain, Europe Follows Grokster's Lead, Wired News, available at http://www.wired.com/news/politics $/ 0,1283,68418,00 . h t m l$.

39 Proposal for a European Parliament and Council Directive on criminal measures aimed at ensuring the enforcement of intellectual property rights/ Proposal for a Council Framework Decision to strengthen the criminal law framework to combat intellectual property offences, COM (2005)276 (July 12, 2005).

40 Id. (emphasis added). ness of this sort of «inducement» standard is highly problematic from the perspective of the entrepreneur - as well as the consumer and the policy-maker - in the digital age. ${ }^{41}$

\section{Grokster's Potential Impact}

At first glance, Grokster has gone some distance toward clarifying under what circumstances the distributor of a dual-use product can be held secondarily liable for the infringements committed by its users. Against the backdrop of Grokster, distributors of dual-use products have to answer a series of questions in order to determine their liability exposure. ${ }^{42}$ First, they have to determine whether they actively encouraged or promoted infringements by their users. If yes, a distributor can be held liable as a contributory infringer based on the inducement rule adopted in Grokster. If not, liability depends on the question whether the distributor has actual knowledge of specific infringements and the capability to stop those infringements. If yes, the distributor is liable when the Ninth Circuit's Napster standard applies. If no, the question becomes whether the product is capable of substantial noninfringing uses. If yes, the distributor enjoys Sony's safe harbor. If no, however, the distributor is liable as a contributory infringer, because courts will impute the requisite intent to encourage infringement to her. ${ }^{43}$

However, things are less clear when taking a closer look at two specific elements in this algorithm. First, as previously discussed, it remains uncertain what activities will qualify as an «active inducement.» Is an advertising slogan like «rip, mix, and burn» for Apple's iPod ${ }^{44}$ already an inducement of copyright infringement as some observers have point-

41 For further discussion, see, e.g., Urs Gasser, Draft EUDirective Sets Forth Criminal Law Provisions Aimed at Fighting IPR Infringements, available at http://blogs.law. harvard.edu/ugasser/2005/07/15\#a 102, Urs Gasser, Follow-up on IPR-II Enforcement Directive, available at http://blogs. law.harvard.edu/ugasser/2005/07/15\#a 103, John Palfrey, New Proposed EU IPR Directive, available at http://blogs.law.harvard.edu/palfrey/2005/07/15\#a897], and Bruce Gain, supra note 38.

42 David Post, The Impact of 'Grokster, 27 Natl. L.J. 10, (Aug. 3, 2005), at 10.

43 See also, Post, supra note 42.

${ }^{44}$ See, e.g., Press Release, Apple, Apple Presents iPod, at http:/www.apple.com/pr/library/200l/oct/23ipod.html (October 23, 2001). 
ed out ${ }^{25}$ Or would media outlets run the risk of being held secondarily liable where they direct readers of an online report via link to copyright infringing technology? ${ }^{46}$ It is almost certain that marketing operations will at least be checking in with their general counsel's office before running a provocative advertisement of any sort.

Second, the Supreme Court has not clarified what counts as «substantial noninfringing uses.» As noted above, the majority opinion avoided addressing this question at all, while the two concurring opinions, each joined by three justices, took a different position. Justice Breyer's concurring opinion regarded evidence that showed that roughly $10 \%$ of the files shared over the networks were noninfringing as sufficient under Sony's «substantial noninfringing use» standard, ${ }^{47}$ especially in light of the fact that there was a «reasonable prospect of expanded legitimate uses over time. $\rangle^{48}$ Justice Ginsburg disagreed with this finding, stating instead that the record evidence was insufficient to conclude that the software at issue was a product with substantial non-infringing uses. Rather, the software was overwhelmingly used to infringe, infringement was the primary source of revenue from the product, and, according to the Ginsburg opinion, there was no reasonable prospect that commercially significant noninfringing uses were likely to develop over time. ${ }^{49}$

4s See, Eric Gwinn, File-sharing Services Can Be Held Liable For Illegal Activities of Clients, Chi. Trib., June 28, 2005.

46 For such a scenario, see LG München, Decision of March 7, 2005, Az. 210 3220/05, available at http:/www.beckmannundnorda.de/linkhaftungpresse.html, where the online news media outlet, Heise online, was held liable for providing a link to a site which provided illegal software for the copying of CDs and DVDs. For an English account of the case, see Heise to File Constitutional Complaint Against Hyperlink Ban, at http://www.heise.de/english/ newsticker/news/63474.

47 MGMet al., $125 \mathrm{~S}$. Cl. at 2789 ("That leaves some number of files near $10 \%$ that apparently are noninfringing, a figure very similar to the $9 \%$ or so of authorized time-shifting uses of the VCR that the Court faced in Sony.").

48 Id, at 2789. Such legitimate uses included: sswapping of: research information (the initial purpose of many peer-topeer networks); public domain films (e.g., those owned by the Prelinger Archive); historical recordings and digital educational materials (e.g., those stored on the Internet Archive); digital photos (OurPictures, for example, is starting a P2P photo-swapping service); (shareware) and freeware) (e.g., Linux and certain Windows software)... " 49 among others. Id., at 2790 (citing other sources).
To sum up, Grokster has not clarified the reach of copyright law's existing secondary liability doctrines, but adopted a new one and presented a 3-3 split, with three abstentions, on the question whether Grokster was capable of substantial noninfringing uses. ${ }^{50} \mathrm{Con}$ sequently, there is no such thing as a bright-line rule for technologists to make reliable ex ante determinations regarding what crosses the line of secondary copyright liability in the Post-Grokster World.

This sort of increased legal uncertainty in a quicksilver technological environment is likely to have chilling effects on innovation and entrepreneurship in the future. ${ }^{51}$ Especially the prospect of extended, factspecific, and costly litigation ${ }^{52}$ through which arguments of the sort sketched above would be tested and that, if successful, would result in statutory damages far in excess of the actual resultant injury to copyright owners, ${ }^{53}$ might discourage potential innovators and investors, causing them to abandon ventures that would have redounded to the benefit of society at large. ${ }^{54}$ How this dynamic will play out is in the hands of the courts that now interpret the Grokster decision. In one early read, a federal court in Illinois explicitly cited Grokster in rejecting a claim of secondary liability brought against a software developer in a dispute over the use of typeface fonts and which implicated the inducement theory. ${ }^{55}$

so See also, Fred von Lohmann, Remedying Grokster, July 25, 2005, available at http://www.eff.org/deeplinks/archives/003833.php\#003833; Post, supra, note 42.

51 See Brief of Amici Curiae Internet Law Faculty in Support of Respondents, Metro-Goldwyn-Mayer Studios Inc., et al. v. Grokster, Ltd., et al. (Case No. 04-480), available at http://cyber.law.harvard.edu/briefs/groksteramicus.pdf.

52 Especially if the Ginsburg approach would prevail. See, supra Section III.1.

53 Brief of Amici Curiae Internet Law Faculty, supra note 51, at $10-11$.

54 For example, one innovative product which might be threatened is Slingbox, a "place-shifting»-device that enables TV viewers to route the live TV signal coming into their homes to a portable device via broadband connection. See Andre Wallenstein, Slingbox could spark new lawsuits, The Hollywood Reportercom, July 06, 2005, available at $\mathrm{http}: / / \mathrm{ww}$.hollywoodreporter.com/thr/article_display.jsp?vnu_content_id=1000973572. Other observers have argued that Grokster might put emerging podcasting services at risk. See Katie Dean, Grokster May Haunt Podcasting, Wired New, June 29, 2005, available at http://www.wired.com/news/digiwood/0, 1412,68034,00. html.

55 See Monotype Imaging, Inc., et al. v. Bitstream, Inc. Civ. No. 03 C 4349 (N.D. Ill., July 12, 2005) at http://www. phillipsnizer.com/library/cases/lib_case398.cfm. One pen- 
Large, established technology players such as producers of consumer electronic equipment may have recourse to lawyers for costly legal advice. In contrast, digital entrepreneurs in their garages might not have the resources or incentives to work out the subtle Grokster line or to get approval of copyright owners before launching new ventures. This, in turn, would both constrict and slow the flow of new ideas sharply. ${ }^{56}$

Last but not least, it remains an open question as to Grokster's impact on P2P software and file-sharing. On the one hand, it seems straightforward that the Groksters of this world will avoid advertising messages that suggest infringing uses. The producers of services such as eDonkey, a large P2P service, have begun to make the move away from a free service to a pay-per-use model, which itself may not be a terrible thing..$^{57}$ Reportedly, P2P advocates began discussing ways to distribute P2P applications without suggesting intent to induce infringement. ${ }^{58}$ Some argue that the developers of $\mathrm{P} 2 \mathrm{P}$ software, many of them sharing values represented by certain elements of the global open source community, are relatively unconcerned about the end uses of their creations and «are motivated primarily by a set of norms that emphasize creative problem solving and contributions to the coding community. $\rangle^{59}$ Viewed from that angle, it does not come as a surprise that new «closed networks» (also known as «darknets») like Freenet have started to proliferate - networks, where only individuals get connected who trust each other and that are much more difficult to "police». ${ }^{60}$ On the other hand, it seems unlikely that Grokster - targeting distributors of P2P software - will shape persistent file-sharing norms which even seem to survive legal actions against individual file-sharers. ${ }^{61}$

\section{Conclusion}

The United States Supreme Court's Grokster decision added new questions and has not, as many wished for, eliminated uncertainty with regard to traditional doctrines of secondary liability. These questions at the intersection of law and technology with potential impact on the culture of digital entrepreneurship must ultimately be answered by the lower courts in the months and years to come. In this light, today's clear winners of the Grokster opinion are IP lawyers, while entrepreneurs, consumers, and society at large alike share the risks and costs of chilling effects on innovation. ${ }^{62}$ The true impact of the Grokster decision may not be known for decades. ding case which may also involve the application of the Grokster inducement rule is that brought by Marvel Entertainment against NCSoft and Cryptic Studios for the design of their online game City of Heroes. Marvel charges that the game's character creation engine sfacilitates, and indeed, encourages players to create and utilize heroes that are nearly identical in name, appearance and characteristics to characters belonging to Marvel.» Daniel Terdiman, Marvel Battles Role Players, Wired News, Nov. 16, 2004, at http:www.wired.com/news/games/0,2101,65722,00.html.

s6 Brief of Amici Curiae Internet Law Faculty, supra note 51, at 12 .

57 Nate Mook, P2P Future Darkens as eDonkey Closes, Beta News, September 28, 2005, available at http://www.betanews.com/article/P2P_Future_Darkens_as_eDonkey_ Closes/I 127953242

sB David Opderbeck, Peer-to-Peer Networks, Technological Darwinism, and Intellectual Property Reverse Private Attorney General Litigation, July, 2005, at 33, n. 138 and accompanying text, http://ssin.com/abstract $=764825$.

59 Id. at 33 .
60 See, e.g., J. D. Lasica, Darknet: Hollywood's War Against the Digital Generation (2005). For an analysis in the aftermath of the Grokster ruling, see John Markoff, New FileSharing Techniques Are Likely to Test Court Decision, N. Y. Times, August I, 2005.

6 See, e.g., Andrew Parker, The True Picture of Peer-to-Peer Filesharing, available at http://www.cachelogic.com/research/slidel.php.

62 See also Palfrey, supra note 33. 


\section{Schweizerische Zeitschrift für Wirtschafts- und Finanzmarktrecht}

Heralusgeber:

P. Nobel (Vorsitz) • II. C.. von der (Tone - M. (jiovanoli

(j. Hertig • C. Iluguenin • A. von Planta • H. Peter • W. A. Stoffel

L. Théveno $\bullet$ II. P. Waller • R. II. Weber • I). \%obl

$2 / 06$

Leitartikel / Articles de fond

Roger Groner

Art. 52 AHVG - Praxis und Zweck der Arbeitgeberhaftung

Pierre-Marie Glauser / Marc-Antoine Borel

La responsabilité pénale du réviseur en matière de soustraction de TVA

Antoine Eigenmann

Projet de loi sur le dépôt et le transfert des titres intermédiés, aspects choisis

Urs Gasser / John G. Palfrey

Catch-as-Catch-Can: A Case Note On Grokster

\section{Kurzbeiträge}

\section{Wolfgang Zürcher}

Die Pflicht zur Aktualisierung des Prospektes während der Zeichnungsfrist beim Börsengang

\section{Europareport}

Thomas Lübbig / Christian Pitschas

Europareport

Zusammenfassung der Rechtsprechung / Résumé de la jurisprudence

Recent developments in Swiss competition law

By Christian Bovet

\section{Bemerkungen zur Rechtsprechung}

Verfügung der Übernahmekammer der Eidgenössischen Bankenkommission vom 19. September 2005 i. S. Saia-Burgess Electronics Holding AG, Murten Mit Bemerkungen von Peter Nobel

Auskunft und Einsicht im Konzern

Entscheid des Schweizerischen Bundesgerichts vom 2. November 2005 (4C.81/2005), BGE 132 III 71, i.S. A. Beteiligungen AG (Beklagte und Berufungsklägerin) gegen $\mathrm{B}$. AG (Klägerin und Berufungsbeklagte)

Mit Bemerkungen von Matthias Nänni und Hans Caspar von der Crone

\section{Schulthess $S$}

